\title{
Predictors of E-government Services Adoption: A Case Study of Russian Students in China
}

\author{
Isaac Kofi Mensah, Piankova Vera, Mi Jianing \\ Department of Public Administration, School of Management, Harbin Institute of Technology, Harbin, China \\ Email address: \\ 185842364@qq.com (I. K. Mensah), pyankova_v@bk.ru (P. Vera), mijianing@126.com (Mi Jianing)
}

\section{To cite this article:}

Isaac Kofi Mensah, Piankova Vera, Mi Jianing. Predictors of E-government Services Adoption: A Case Study of Russian Students in China. International Journal of Management and Fuzzy Systems. Vol. 3, No. 5, 2017, pp. 67-74. doi: 10.11648/j.ijmfs.20170305.12

Received: April 14, 2017; Accepted: April 26, 2017; Published: October 31, 2017

\begin{abstract}
Electronic government is the use of Information and Communication Technologies in the public administration processes to provide better public services to citizens and the general public. The adoption of e-government services is vital for the success of e-government projects. The purpose of this study is to investigate factors influencing the Russian students in China willingness to adopt and use e-government services. Predictors such as perceived usefulness, perceived ease of use, perceived service quality, citizen trust and language barrier would be explored. The Technology Acceptance Model would be used as the theoretical framework for the study. The questionnaire instruments would be administered to 500 Russian students in the City of Harbin. The data gathered would be captured and analyzed with SPSS while a further analysis would be conducted using the Structural Equation Model (SEM). Based on the data analysis, appropriate recommendations would be offered to improve public service delivery through e-government not only to Chinese citizens but foreign nationals who reside in China as well.
\end{abstract}

Keywords: E-government, E-government Services, Adoption, Technology Acceptance Model (TAM), Russia, China

\section{Introduction}

Electronic government (e-government) is considered as the strategies, organizational reforms and processes provided by the power of the Information and Communication Technology (ICT) to enhance access to and delivery of government information and services to citizens, businesses, government employees and other agencies [1]. E-government is defined as the use by the government of innovative Information and Communication technologies (ICTs) such as web-based internet applications to provide citizens and businesses with more convenient access to government information and public services as well to improve the quality of the services [2]. It is also meant to provide greater opportunities for participation in democratic institutions and processes [2]. The adoption of e-government by using ICT in the public administration processes is expected to make government operations more accessible, effective, and accountable and transparent [3]. E-government as a transformational tool seeks to enhance the quality of life of citizens through redefining of the interaction between citizens and government [4]. E-government is seen as the revolutionary phenomena which seek to bring about a fundamental change in the entire public administration structure, values, culture and the manner of dealing with business as well as citizens [5]. The public administration of state institutions has been criticized for poor performance, slow and inefficient service delivery and stringent rigid regulations [6]. The adoption of e-government is expected to address these challenges and criticisms.

The important factors affecting the success of egovernment are the governing factors, the technical factors and the organizational factors [7]. Weerakkody et al [8] also identified four major factors determining the success of egovernment initiatives; these are political factors, technological factors, organizational factors and social factors. According to Weerakkody et al., [8], the political factor has to do with major support from the government through the provision of funding, leadership and political commitment to the development of e-government. This operation includes setting laws, operational regulations, and contractual regulations. Another critical factor for the success of e-government is the technological factor which includes setting the information technology standards for hardware, 
software, data, information compatibility of different systems and technologies, the safety of data and privacy etc. [8]. The organizational factor has to do with changes in the organizational structures and cultures, decentralization of power in relations to functions and internal processes while the social factors have to do with training and educating the public on new technologies and breaching the gap in terms of ICT access and use with regard to gender, age, income, and language [8].

The interaction of Government with major actors in society such as citizens, business etc. has led to the creation of e-government services to meet the demands and expectations of all these actors. These forms of e-government are Government-to-Government (G2G), Government-toCitizens (G2C), Government-to-Businesses (G2B) and Government-to-Employees (G2E). The Government-toGovernment (G2G) form of e-government provides government's agencies and departments to communicate and share vital information across different agencies, departments, and ministries. It could be the sharing of information and data within and among sector agencies or between local governments agencies with a central government agency. The Government-to-Citizen type of egovernment (G2C) enables the public sector agencies and government machinery to provide public services online to citizens in the form of downloadable forms, uploading forms, application for birth certificates, acquisition of passports, payment for utilities, filing of tax and also by providing critical information with regard to public policy formulation and regulations. This form of e-government can also serve as a platform for citizens to provide essential feedback to government and its agencies with regard to service delivery and inputs into public policy formulation. The Governmentto-Business (G2B) form of e-government is initiated to ease and smooth interaction between government agencies and the business sector. This type of e-government services provides an opportunity for the business community to engage in transactions and procurement as well as tendering processes with government agencies. Finally, the Government-to Employee (G2E) provides services to manage the communication and interaction with public sector workers with a goal to ensure the creation of a paperless office. All these forms of e-government importantly provide a two-way communication between a government with the citizenry, businesses, government itself and public sector employees. This two-way communication enables these actors; citizens, businesses, employees, and agencies to provide valuable feedback about government service delivery and also contribute to refining policy regulations.

The focus of this study is about the Government-to-Citizen (G2C) form of e-government but in this case, we are dealing with non-citizens i.e. Government-to-non-citizens (G2NC). Globalization has made the world a small village with people migrating to countries to settle, work, and study and for tourism. Once people migrate and live in another country they would have to enjoy public services from the government agencies in such a country and so the design and implementation of e-government services by the government must be carried out to cater for not only citizens but for foreign nationals too. Hence the focus of this study is on the Foreign Russian nationals (students) in China.

The objective of this study is to examine the factors determining the willingness of Russian students in China to adopt and use e-government services. The following research questions would be investigated to achieve the objective of this research.

a. Does perceived usefulness of e-government services have a significant direct on the willingness of Russian students in China to adopt and use e-government services?

b. Does perceived ease of use of e-government services have a significant direct on the willingness of Russian students in China to adopt and use e-government services?

c. Does perceived service quality of e-government services have a significant direct on the willingness of Russian students in China to adopt and use egovernment services?

d. To what extent does Language Barrier have a significant direct on the willingness of Russian students in China to adopt and use e-government services?

e. Does citizens' trust have a significant direct on the willingness of Russian students in China to adopt and use e-government services?

f. Does language barrier have a direct impact on the perceived service quality of e-government services?

g. Does language barrier have significant direct impact on the perceived ease of use of e-government services?

h. Does language barrier moderate the significant direct impact of perceived service quality on the willingness to use e-government services?

i. Does language barrier moderate the significant direct impact of perceived ease of use on the willingness to use e-government services?

\section{Literature Review and Research Theoretical Framework}

Several theories have been advanced to explain the acceptance and behavior of users with regard to Information Technology and its related applications. Some of this proposed technology acceptance theories are Theory of Reason Action (TRA) [9], Theory of Planned Behavior (TPB) [10], United Theory of Acceptance and Use of Technology (UTAUT) [11], Innovation Diffusion Theory [12] and Technology Acceptance Model (TAM) [13]. For the purpose of this research, the Technology Acceptance Model (TAM) would be used as the theoretical foundation for this study.

The Technology Acceptance Model (TAM) by Davis [13] is the widely used technology acceptance theory applied to understand and predict the behavioral acceptance of information technology systems. It has been applied in varied 
different research such as e-commerce and e-governance/egovernment. TAM proposed two very important factors such as Perceived usefulness and perceived ease of use as the major and relevant to explaining the behavioral intention to use. Davis [13] defined perceived usefulness as the subjective belief that the use of particular information and technology related application would enhance his or her job performance. The perceived ease of use is defined as the extent to which the user believe that the use of an information technology system would be free of effort or challenges. Davis [13] emphasized that these factors are the major determinants of actual system use. According to Davis [13], perceived usefulness and perceived ease of use are influenced by external variables such as social factors, cultural factors, and political factors whilst the behavioral intention is the measure of probability or tendency of an individual using technology related applications. The technology Acceptance Model is depicted in Figure 1.

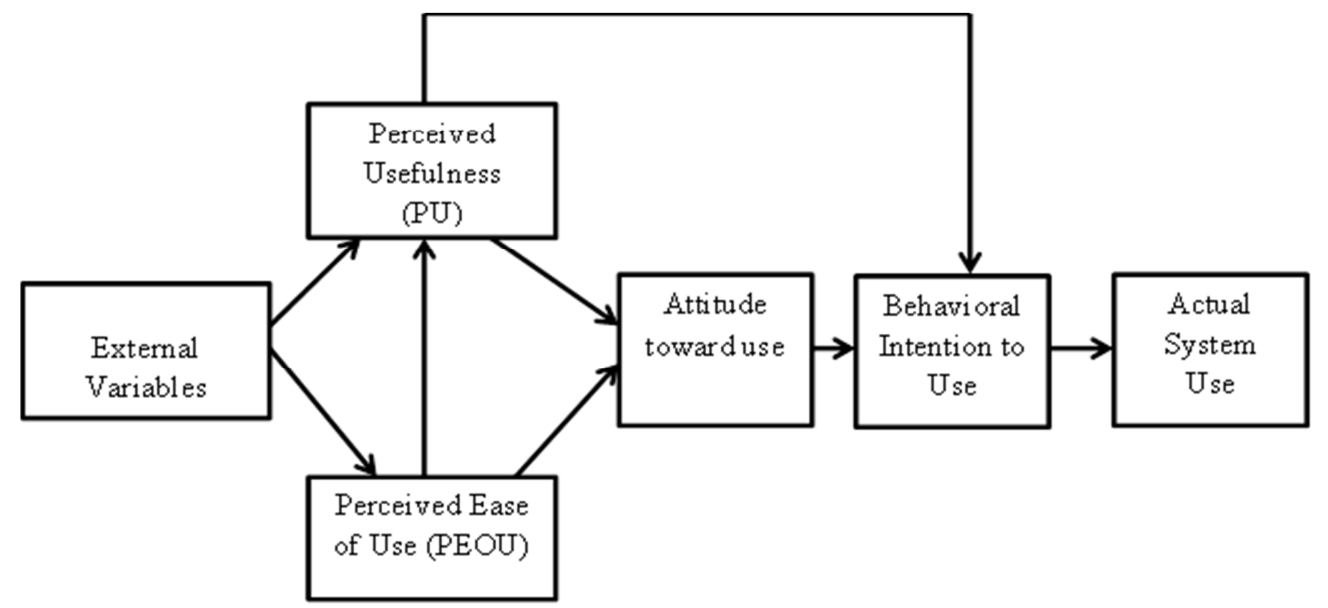

Figure 1. Technology Acceptance Model (TAM) [13].

Over the years, The TAM has undergone several modifications by researchers by including new variables to explain the adoption of technology in specific contexts. For instance, TAM was modified to include the construct compatibility in Technology Acceptance Model [14]. It was also modified by adding playfulness factors to understand the acceptance of the World Wide Web [15]. Further, Lim [16] modified TAM by including factors such as social influence, experience, self-efficacy and perceived risk. TAM was again modified to include two categories of perceived usefulness such as near-term and long-term [17] whilst Van de Heijden [18] included perceived entertainment value and perceived presentation attractiveness.

\subsection{TAM and E-government Adoption}

In the field of e-governance/e-government, the Technology Acceptance Model (TAM) has been applied to explain the acceptance and use of e-government services. The following sections would discuss studies which have applied the Technology Acceptance Model (TAM) to predict the adoption of e-government services.

Appling TAM in examining the adoption of e-government services among the citizens in selected districts in Tanzania, Komba [19] found out that social influence was a determining factor in the adoption of e-government services in Tanzania. In Sri Lanka, Ranaweera. [20] Found that trust was vital and significant in the readiness of people Sri Lanka to use e-government services. Lai and Pires [21] provided evidence through TAM that information quality, system quality, and social influence were success factors determining the adoption of e-government services. Cegarra-Navarro J., et al [22] also tested the core constructs of TAM and revealed that perceived usefulness, perceived ease of use and attitudes were influencing factors in the use of e-government services. Determining the readiness of Teachers in Greece to adopt egovernment services, it was revealed that cognitive and intrinsic factors were positive significant in influencing the intention to use e-government websites [23]. In another study to determine user attitude towards e-government initiatives in the Kingdom of Saudi Arabia, perceived ease of use, perceived usefulness and attitudes were all important factors for the usage of e-government in the Kingdom of Saudi [24].

Further, TAM was adopted to examine the acceptance of egovernment services in Malaysia and the results indicated that perceived usefulness, perceived ease of use, compatibility, interpersonal influence, external influence, self-efficacy, facilitating conditions, attitude and subjective norms were all positive determinants of Malaysians to adopt and use e-government services [25]. In exploring the business sector perspectives towards the adoption of egovernment services, Alghamdi and Beloff, [26] demonstrated that perceived benefits, awareness, previous experience and regulations and policies were significant factors influencing the business sector towards the adoption of e-government services in Saudi Arabi.

\subsection{Discussion of the Factors Used in This Study}

The factors such as perceived usefulness, perceived ease of use, perceived service quality, language barrier and citizen trust applied to conduct this study are discussed briefly below: 


\subsubsection{Perceived Usefulness (PU)}

The perceived usefulness is one of the major determinates of technology adoption proposed by Davis [13]. It is conserved as the degree to which a person believes that using a particular technology application would contribute to improving his/her job performance [13]. The perceived usefulness in TAM is similar to relative advantage factor in the DOI and performance expectancy in UTAUT [11]. Perceived usualness has been established to have a direct impact on the Actual Use [27, 28, 29, 30]. PU also has a direct impact on the behavioral intention to use. In the context of e-government, PU has been investigated to have a positive significant influence on the intention to adopt and use e-government services.

\subsubsection{Perceived Ease of Use (PEOU)}

Perceive ease of use has also been found to be essential to the success and adoption of technology related applications. It is considered as the extent to the use of a system would be free from any challenge or difficulties [13]. It is also considered similar to the effort expectancy in UTAUT [11]. PEOU has a direct determinate on behavioral intention (BI) $[31,32,33]$. Studies have supported the indirect impact of perceived ease of use (PEOU) on BI (Behavioral Intention) through perceived usefulness (PU) [34, 28, 35].

\subsubsection{Perceived Service Quality (PSQ)}

The service quality of e-government services has an impact on the adoption and use e-government services based on service performance, citizens' expectations towards service delivery. E-government service quality can be considered as the citizen's expected service delivery and perceived service. Service quality is considered as the degree to which a service delivery meets the expectations of citizens $[36,37,38]$. Service quality is also defined as the comparison between citizens' expectations and perceptions towards service delivery [39]. According to Sharma [40], the primary objective for the development of e-government services is to bridge the gap between service delivery and citizens' expectations. The provision of high-quality service by the government through e-government services can contribute to enhancing the effectiveness of governance thereby achieving a higher degree of participation, awareness, and engagement between government and its users [40]. The preference of citizens and the general public to use e-government services is high due to the convenience of service availability $24 / 7$ [40].

There are different e-service quality dimensions which have been proposed by several scholars. Parasuraman et al., [39] proposed 10 e-service quality dimensions such as reliability, responsiveness, competence, Access, courtesy, communication, credibility, security, understanding, and Tangibles. Yang et al., [41] also outlined 5 dimensions of eservice quality which are usability, the usefulness of content, adequacy of information, accessibility and interaction. Fassnacht and Koese [42] have described 12 e-service dimensions such as environment quality, delivery quality, outcome quality, graphic quality, clarity of layout, the attractiveness of service selection, information quality, ease of use, technical quality, reliability, functional benefits and emotional benefits. Further, Cristobel et al., [43] identified 4 e-service dimensions such as customer service, web design, assurance and order of management whilst Sohn and Tadisina [44] also proposed 6 dimensions of e-service quality like trust, customized communication, ease of use, website, content functionality, reliability and speed of delivery. These service quality dimension enumerated above have been explored with respect to Internet banking users [45, 46] but remains largely unexplored in the e-government adoption context [40].

The service quality dimensions such as reliability, security, efficiency, and responsiveness were found to be major determinants influencing the willingness to use e-government services in Oman [40]

\subsubsection{Language Barrier (LB)}

The United Nations E-government survey 2012 reported that language and literacy is one the major challenges confronting the adoption and use of e-government. It also indicated that issues such as gender, income; location and age affect the adoption and use of e-government services around the world. Language has been found to be significant in affecting perceived ease of use and perceived usefulness of egovernment services in a study conducted in the UAE [47].

\subsubsection{Trust}

The element of trust as a predictor has been found to influence the intention to adopt and use e-government services and for the success of e-government projects [48]. Trust is considered as a psychological state comprising the intention to accept vulnerability based on positive expectations of the intentions or behavior of another party [49]. According to Mayer et al [50] trust is the willingness of a party to be vulnerable to the actions of another party based on the expectation that the other party will perform or act in particular action important to the trustor, irrespective of the ability to monitor or control that other party. There are different perspectives and approaches to understanding the concept of trust. These approaches include the economic approach, the managerial approach, the human computer interaction approach and the sociology approach and technology approach. The economic perspectives has to do with building trust with respect to transactions [51, 52], the managerial perspective concerns the persuasion of consumers to build [53], the computer interaction perspectives is focused on building the trust of consumers in information and communication technology applications $[54,55]$ and the sociology perspective has to do with regard to interpersonal and group interactions [56]. The technology perspective is concerned with the adoption and use of new and modern technology related applications $[57,58]$.

The concept of trust in relation to e-government adoption has to do with trust in government and trust in the Internet. These categories of trust in respect of e-government services are crucial for achieving high patronage and for egovernment to succeed. The trust in government is the ability 
of citizens to have confidence that government has the potential and resources including the political will to successfully implement e-government projects. Trust in the Internet is considered as the strong confidence that the use of the internet to provide public services would be secure and privacy of users are not violated. Low levels or lack of trust in both governments' potential to implement e-government and in the internet will lead to the apathy of citizens and the public towards the e-government initiatives of government [59]. Both the trust in the Internet and in government have been determined as a predictor of e-government adoption $[60,61,62,63]$.

\section{Research Model and Hypotheses}

\subsection{Research Model}

The research model is depicted in Figure 2. Perceived usefulness, perceived ease of use, perceived service quality, language barrier and citizen trust are considered as the independent variables whilst the willingness to use egovernment services is the dependent variable. It is assumed that all the independent variables would have a positive impact on the dependent variable. The language barrier is considered as a moderating variable as well. It moderates the direct impact of both perceived service quality and perceived ease of use on the willingness to use e-government services.

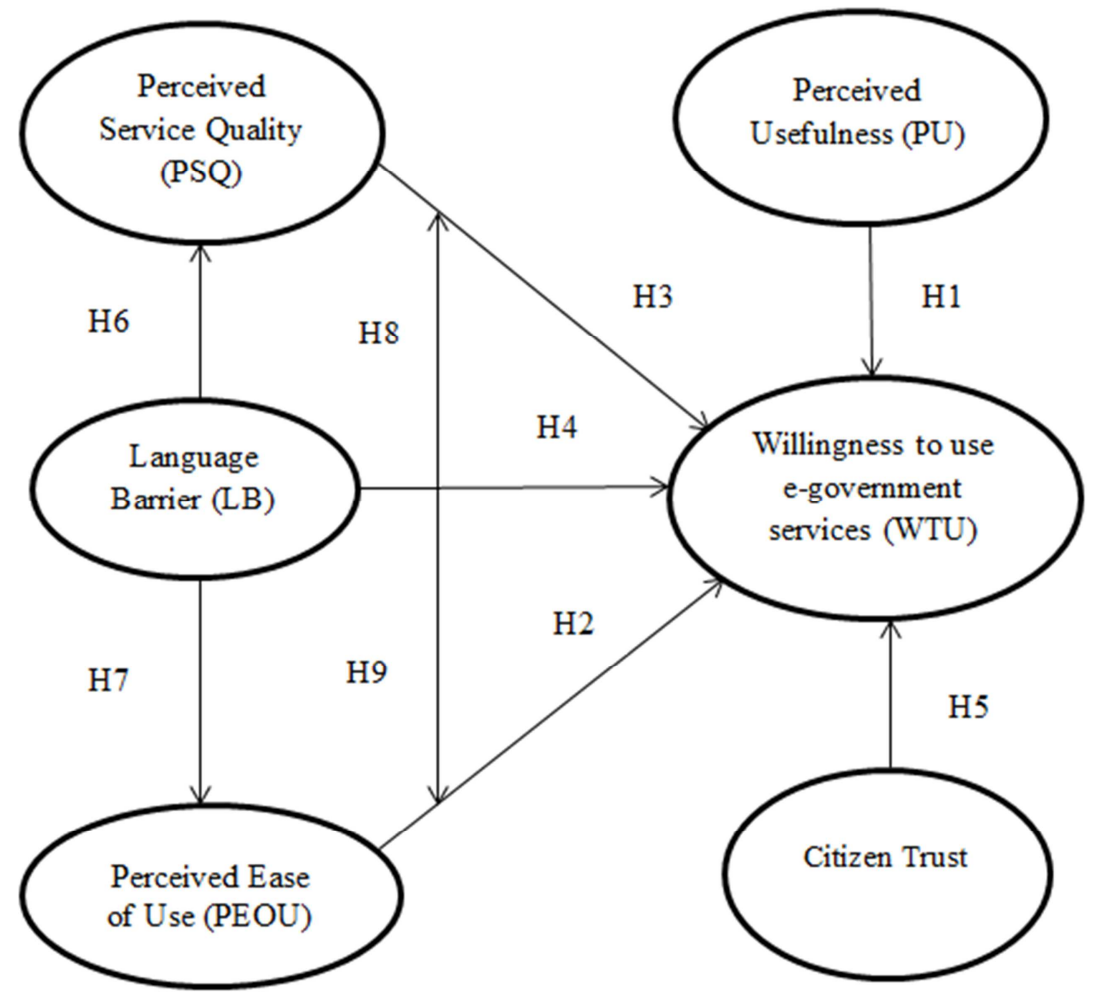

Figure 2. Research Model.

\subsection{Research Hypotheses}

This research would attempt to investigate the following hypotheses based on the research model depicted in Figure 2.

Hypothesis One (H1): Perceived usefulness of egovernment services has a significant direct impact on the willingness of Russian students in China to adopt and use egovernment services.

Hypothesis Two (H2): Perceived ease of use of egovernment services has a significant direct impact on the willingness of Russian students in China to adopt and use egovernment services.

Hypothesis Three (H3): Perceived service quality of egovernment services has a significant direct impact on the willingness of Russian students in China to adopt and use egovernment services.

Hypothesis Four (H4): Language barrier has a significant direct impact on the willingness to Russian students in China to adopt and use e-government services.

Hypothesis Five (H5): Citizens' trust has a significant direct impact on the willingness of Russian students in China to adopt and use e-government services.

Hypothesis Six (H6): Language barrier has a significant direct impact on the perceived service quality of egovernment services.

Hypothesis Seven (H7): Language barrier has a significant direct impact on the perceived ease of use of e-government services.

Hypothesis Eight (H8): Language barrier moderates the significant direct impact of perceived service quality on the willingness to use of e-government services.

Hypothesis Nine (H9): Language barrier moderates the significant direct impact of perceived ease of use of egovernment services on the willingness to adopt and use egovernment services. 


\section{Research Methodology}

The data for this research would be collected from Russian students studying in China. Specifically, the sample for this study would be taken from the City of Harbin, located in Heilongjiang, one of the Provinces in China. A research questionnaire instrument would be designed and administered to 500 potential respondents (Russian Students). The questionnaire instruments would be translated into the Russian Language because the targeted population for this study's language is Russian. The instrument would be measured on five Likert scales from 1= strongly Disagree to $5=$ Strongly Agree. Each variable would contain five unique and unrelated questions. The data would be captured and analyzed with SPSS version 20 while a further in-depth analysis would be conducted using the Structural Equation Model (SEM) by conducting Confirmatory Factor Analysis (CFA) and Path Analysis (PA). This would be done using AMOS Graphics. The graphical representation of the moderating effect would be plotted with the software called Interaction 1.7.2211. In order to remove any ambiguity from the questionnaires, it will be piloted and pre-tested.

\section{Future Work}

This study is an ongoing research work and future work would have to be done to complete fully the expected work. The design of the research questionnaire instrument has been completed. The future work would involve the following:

a. Administration of the research questionnaire instrument, collection, crosschecking to remove incomplete and uncompleted questionnaires prior to data entry and capture with SPSS

b. Analysis of the data would be done once the data has been successfully captured. Results of the analysis would be reported and inculcated into the final full paper of this research. Further, based on the data analysis, conclusions would be made and appropriate recommendations prescribed.

\section{Conclusion}

The conduct of this study is significant because it is one of the major studies which focus on non-citizens within a country with regard to e-government service adoption. The majority of e-government adoption research have mostly focused on the citizens of the specific country but this currently study seeks to go beyond the citizen-countryspecific e-government adoption studies. The provision of public services by Government and its agencies is not only meant for the citizenry but also non-citizens who reside in such a country for work or study. This in effect means that the adoption and implementation of e-government services by Government should be designed to meet the service quality expectations of non-citizens too. Hence this study would seek to examine factors influencing Russian students in China to use e-government services in China. The outcome of this study would provide usefulness insight into factors determining the willingness of foreigners to use egovernment services in China. The recommendations from this research would help towards the implementation of egovernment in China, particularly towards foreign nationals in China. This would contribute significantly to enriching the e-government literature.

\section{References}

[1] Kefallinos, D., Lambrou, M., Sykas, E.: An Extended Risk Assessment Model for Secure EGovernment Projects. International Journal of Elec-tronic Government Research. 5, 72-92 (2009)

[2] Fang, Z.: E-Government in Digital Era: Concept, Practice, and Devel-opment. International Journal of The Computer, The Internet and Man-agement. 10, 1-22 (2002).

[3] Wangpipatwong, S.: Quality Enhancing the Continued Use of E-Government Web Sites: Evidence from E-Citizens of Thailand. Interna-tional Journal of Electronic Government Research. 5, 19-35 (2009).

[4] Kumar, V., Mukerji, B., Butt, I., Persaud, A.: Factors for Successful e-Government Adoption: a Conceptual Framework. The Electronic Journal of e-Government. 5, 63 76 (2007).

[5] Alshehri, M., Drew, S., Alfarraj, O.: A Comprehensive Analysis of E-Government Services Adoption in Saudi Arbaia: Obstacles and Chal-lenges. International Journal of Advanced Computer Science and Appli-cations. 3, (2012).

[6] Noore Alam Siddiquee, (2016) "E-government and transformation of service delivery in developing countries: The Bangladesh experience and lessons", Transforming Government: People, Process and Policy, Vol. 10 Issue: 3,pp. 368-390, doi: 10.1108/TG-09-2015-0039 Permanent link to this document:http://dx.doi.org/10.1108/TG-09-2015-0039

[7] Altameem, T., Zairi, M. and Alshawi, S. (2006), "Critical success factors of E-Government: a proposed model for EGovernment implementation", Innovations in Information Technology 2006, Dubai, November 2006, pp. 1-5

[8] Weerakkody, V., El-Haddadeh, R. and Al-Shaf, S. (2011), "Exploring the complexities of e-government implementation and diffusion in a developing country some lessons from the state of Qatar", Journal of Enterprise Information Management, Vol. 24 No. 2, pp. 172-196.

[9] Fishbein, M., \& Ajzen, I. (1975). Belief, attitude, intentions and behavior: An introduction to theory and research. Boston: Addison-Wesley.

[10] Ajzen, I. (1985). From intentions to actions: A theory of planned behavior. In J. Kuhl \& J. Beckman (Eds.), Actioncontrol: From cognition to behavior (pp. 11-39). Heidelberg, Germany: Springer.

[11] Venkatesh, V., Morris, M., Davis, G., \& Davis, F. (2003). User acceptance of information technology: Toward a unified view. MIS Quarterly, 27(3), 425-478.

[12] Rogers, E. M. (1995). Diffusion of innovations (4th ed.). New York: Free Press. 
[13] Davis, F. (1989). Perceived usefulness, perceived ease of use, and user acceptance of information technology. MIS Quarterly, 13(3), 319-340

[14] Agarwal, R., and Prasad, J. "A Conceptual and Operational Definition of Personal Innovativeness in the Domain of Information Technology," Information Systems Research (9:2), 1998b, pp. $204-215$.

[15] Ji - Won Moon, Young - Gul Kim "Extending the TAM for a World - Wide - Web context" Information \& Management, $38,217-230$

[16] Missing

[17] Chau, P. Y. K. (1996). “An empirical assessment of a modified technology acceptance model." Journal of Management Information Systems, 13, 185 - 204.

[18] Van der Heijden, H. (2000). "Using the technology acceptance model to predict website usage: Extensions and Empirical Test," Serie Research Memoranda.

[19] Mercy Mlay Komba(2016). Adoption of E-Government Services Among Citizens in the Selected Districts of Tanzania. International journal Of computer science and technology. IJCST Vol. 7, ISSue 3, July - SepT 2016.

[20] H. M. B. P. Ranaweera (2016). Perspective of trust towards egovernment initiatives in Sri Lanka. SpringerPlus (2016) 5:22DOI 10.1186/s40064-015-1650-y

[21] Lai, C, S, A, and Pires, G. (2010) "Testing of a Model Evaluating e-Government Portal Acceptance and Satisfaction" The Electronic Journal Information Systems Evaluation Volume 13 Issue 12010 , (pp35 - 46), available online at www.ejise.com

[22] Cegarra-Navarro J., et al. "The Value of Extended Framework of TAM in the Electronic Government Services" The Electronic Journal of Knowledge Management Volume 12 Issue 1 (pp 14-24) available online at www.ejkm.com

[23] Kostas Zafiropoulos, Ioannis Karavasilis, and Vasiliki Vrana(2012). Assessing the Adoption of e-Government Services by Teachers in Greece. Future Internet 2012, 4, 528544; doi:10.3390/fi4020528

[24] Raed Alotaibi et al, (2014). A Study of Service Users' Attitudes towards E-Government Initiatives in the Kingdom Of Saudi Arabia (IJCSIT) International Journal of Computer Science and Information Technologies, Vol. 5 (6), 2014, 68926901

[25] Norazah Mohd Suki and T. Ramayah(2010). User Acceptance of the E-Government Services in Malaysia: Structural Equation Modelling Approach. Interdisciplinary Journal of Information, Knowledge, and Management. Volume 5, 2010.

[26] Saleh Alghamdi andNatalia Beloff (2016). Innovative Framework for e-Government adoption in Saudi Arabia: A Study from the business sector perspective. (IJACSA) International Journal of Advanced Computer Science and Applications, Vol. 7, No. 1, 2016

[27] Alenezi, H., Tarhini, A., \& Sharma, S. K. (2015). Development of a Quantitative Model to Investigate the Strategic Relationship between Information Quality and EGovernment Benefits. Transforming Government: People, Process and Policy, 9(3), 324-351. http://dx.doi.org/10.1108/TG-01-2015-0004
[28] Alalwan, A. A., Dwivedi, Y. K., \& Williams, M. D. (2016). Customers' Intention and Adoption of Telebanking in Jordan. Information Systems Management, 33(2), 154-178.

[29] Abdullah, F., Ward, R., \& Ahmed, E. (2016). Investigating the influence of the most commonly used external variables of TAM on students' Perceived Ease of Use (PEOU) and Perceived Usefulness (PU) of e-portfolios. Computers in Human Behavior, 63, $\quad$ 75-90. http://dx.doi.org/10.1016/j.chb.2016.05.014

[30] Obeidat, B. Y., Al-Suradi, M., Masa'deh, R., \& Tarhini, A. (2016). The Impact of Knowledge Management on Innovation: An Empirical Study on Jordanian Consultancy Firms. Management Research Review, 39(12), 33-52.

[31] Masa'deh, R., Tarhini, A., Al-Dmour, R. H., \& Obeidat, B. Y. (2015). Strategic IT-Business Alignment as Managers' Explorative and Exploitative Strategies. European Scientific Journal, 11(7), 437-457.

[32] Abdullah, F., \& Ward, R. (2016). Developing a General Extended Technology Acceptance Model for E-Learning (GETAMEL) by analysing commonly used external factors. Computers in Human Behavior, 56, 238-256. http://dx.doi.org/10.1016/j.chb.2015.11.036

[33] Esterhuyse, M., \& Scholtz, B. (2016). The Intention to Use ELearning in Corporations. In Proceedings of the 2nd International Conference on Information Resources Management (pp. 3-18). Cape Town, South Africa.

[34] Altamony, H., Tarhini, A., Al-Salti, Z., Gharaibeh, A., \& Elyas, T. (2016). The relationship between Change Management Strategy and Successful Enterprise Resource Planning (ERP) Implementations: A Theoretical Perspective. International Journal of Business Management and Economic Research, 7(4), 690-703.

[35] Almajali, D. A., Masa'deh, R., \& Tarhini, A. (2016). Antecedents of ERP Systems Implementation Success: A Study on Jordanian Healthcare Sector. Journal of Enterprise Information Management, 29(4), 549-565. http://dx.doi.org/10.1108/JEIM-03-2015-0024

[36] Barbara R. Lewis, Vincent W. Mitchell, "Defining and Measuring the Quality of Customer Service", Marketing Intelligence \& Planning, Vol. 8 Iss: 6, 1990, pp.11- 17

[37] Asubonteng, P., McCleary, K. J. and Swan, J. E., "SERVQUAL revisited: a critical review of service quality", Journal of Services Marketing, Vol. 10, No. 6, 1996, pp.62-81

[38] Wisniewski, M. \& Donnelly., M. Measuring service quality in the public sector: The potential for SERVQUAL. Total Quality management, 7, 1996, pp.357-364.

[39] Parasuraman, A., Zeithaml, V. A., Malhotra, A., 2005. E-SQual: a multiple-item scale for assessing electronic service quality. Journal of Service Research 7 (3), pp.213-233

[40] Sujeet Kumar Sharma, (2015),"Adoption of e-government services", Transforming Government: People, Process and Policy, Vol. 9 Iss 2 pp. 207 - 222 Permanent link to this document: http://dx.doi.org/10.1108/TG-10-2014-0046

[41] Yang, Z., Fang, X., 2004. Online service quality dimensions and their relationships with satisfaction: a content analysis of customer reviews of securities brokerage services. International Journal of Service Industry Management 15 (3), pp.302-326. 
[42] Fassnacht, M., \& Koese, I. (2006). Quality of electronic services. Journal of Service Research, 9(1), 19-37.

[43] Cristobel, E., Flavian, C., \& Guinaliu, M. (2007). Perceived eservice quality (PeSQ): Measurement validation and effects on consumer satisfaction and web site loyalty. Managing Service Quality, 17(3), 317-340.

[44] Changsoo Sohn, \& Suresh K. Tadisina. (2008). Development of e-service quality measure for internet-based financial institutions. Total Quality Management \& Business Excellence, 19(9), 903-918.

[45] Liao, Z. and Cheung, M. T. (2008), "Measuring consumer satisfaction in internet banking: a core framework", Communications of the ACM, Vol. 51 No. 4, pp. 47-51

[46] George, A. and Kumar, G. G. (2014), "Impact of service quality dimensions in internet banking on customer satisfaction", DECISION, Vol. 41 No. 1, pp. 73-85.

[47] Emad Bataineh and Sara Al Mutawa (2016)," An Analysis Study of Factors That Determine E-Services Usage by End Users: A Case Study ", Journal of e-Government Studies and Best Practices, Vol. 2016 (2016), Article ID 371910, DOI:10.5171/2016.371910

[48] Carter, L, Belanger, F., "The utilization of e-government services: Citizen trust, innovation and acceptance factors", Information Systems Journal 15: 5-25, 2005.

[49] Rousseau, D., Sitkin, S., Burt, R \& Camerer, C. (1998). Not so different after all: a cross discipline view of trust. Academy of Management Review 23 (3), 393-404.

[50] Mayer, R. C., Davis J. H. \& Schoorman D. F. (1995). An integrative model of organizational trust. The Academy of Management Revie. 3, 709-734.

[51] Cave, J. (2005). The economics of cyber trust between cyber partners. In Trust and Crime in Information Societies (Mansell and Collins, eds.) Cheltenham: Edward Elgar, 380 427

[52] Guerra, G. A., Zizzo, D. J., Dutton, W. H., \& Peltu, M. (2003). Economics of Trust in the Information Economy: Issues of Identity, Privacy and Security. Technical report. Oxford Internet Institute, Research Report No. 1.
[53] Cavoukian, A. \& Hamilton, T. (2002). The Privacy Payoff. HowSuccessful Business Build Consumer Trust. McGrawHillRyerson Trade

[54] Riegelsberger, J., Sasse, M. A. \& McCarthy, J. D. (2005). The Mechanics of Trust: A Framework for Research and Design. International Journal of HumanComputer Studies. 62(3), 381422.

[55] Lee, J., Kim, J. \& Moon, J. Y. (2000). What makes internet usersvisit cyber stores again? Key design factors for customer loyalty. In CHI '00: Proceedings of the SIGCHI conference on Human factors in computing systems, 305-312, NewYork, ACM Press.

[56] Salovey P. \& Rothman A. (2003). Social Psychology of Health. Psychology press.

[57] Misztal, Barbara A. (1996). Trust in Modern Societie. Cambridge, The Polity Press.

[58] Fukuyama, F. (1995). Trust: The Social Virtues and the Creation of Prosperity. Harmondsworth, Penguin Books

[59] Fukuyama, F. (1995). Trust: The Social Virtues and the Creation of Prosperity. Harmondsworth, Penguin Books.

[60] Belanger, A. \& Carter, L. (2008). Trust and risk in egovernment adoption. Journal of Strategic Information Systems 17, 165-176.

[61] Horst M, Kuttschreuter M. \& Gutteling J. M. (2007). Perceived usefulness, personal experiences, risk perception and trust as determinants of adoption of egovernment services in The Netherlands. Computers in Human Behavior 23, 1838 1852 .

[62] Warkentin, M., Gefen D., Pavlou P. A. \& Rose, G. (2002). Encouraging Citizen Adoption of eGovernment by Building Trust. Electronic Markets, 12(3), 157-162.

[63] Colesca S. (2007). The main factors of on-line trust, Economia. Seria Management, ASE Publishing House, 10(2), 27-37. 